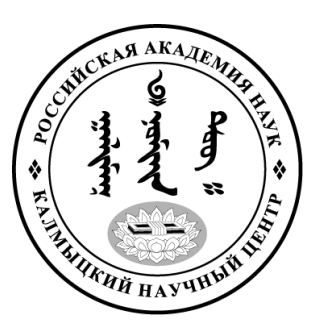

Published in the Russian Federation

Oriental Studies (Previous Name: Bulletin of the Kalmyk Institute for

Humanities of the Russian Academy of Sciences)

Has been issued as a journal since 2008

ISSN: 2619-0990; E-ISSN: 2619-1008

Is. 4, pp. 661-668, 2019

DOI: 10.22162/2619-0990-2019-44-4-661-668

Journal homepage: https://kigiran.elpub.ru

УДК $81 ’ 373.23$

\title{
Официальные и «вторые» имена этнических тувинцев Монголии
}

\author{
Надежда Дарьевна Сувандии \\ ${ }^{1}$ Тувинский государственный университет ( д. 9, Литер В, ул. Монгуша Сата, 667000 Кызыл, \\ Российская Федерация) \\ кандидат филологический наук, доцент \\ ORCID: 0000-0002-3817-2436. E-mail: suvandiin@mail.ru
}

\begin{abstract}
Аннотация. Введение. Статья содержит анализ личных имен и прозвищ («парных» и «домашних», или «вторых» имен) этнических тувинцев Монголии, которые являются одной из малоизученных актуальных проблем современной ономастики тувинского языка. В прозвищах хранится информация о прежней и современной культуре тувинцев зарубежья, в частности Монголии. Основной целью статьи является выявление официальных, а также «домашних» и «парных» имен, т. е. прозвищ, у тувинцев, проживающих в Западной Монголии. Данная научная статья может восполнить пробел в решении этой проблемы в тувинской ономастике. Maтериаль. Основой для анализа стали личные имена и прозвища, собранные автором во время полевых исследований в Баян-Ульгийский и Кобдоский (Ховдский) аймаки Монголии, где проживают этнические тувинцы. Результаты. Проанализировав личные имена и прозвищные наименования, автор пришел к выводу о том, что у тувинцев Западной Монголии в официальных документах записываются личные имена монгольско-тибетского происхождения, а в повседневной жизни используются так называемые «вторые» имена: өг aтmары ‘домашние' или кош аттар 'парные имена', которые указывают на историю, обычаи и традиции их предков. В качестве «домашних» и «парных» имен в прошлые годы давались как исконно тувинские, так и монгольско-тибетские имена, а в настоящее время к ним прибавились и личные имена с уменьшительно-ласкательным значением, что является новшеством в традиции имянаречения у тувинцев Монголии.
\end{abstract}

Ключевые слова: тувинский язык, ономастика, антропонимия, личные имена, прозвища, «вторые» имена, «домашние» имена, «парные» имена

Благодарность: Исследование выполнено при финансовой поддержке РФФИ в рамках научного проекта № 19-012-00073 «Трансформационные процессы в ономастике народов Центральной Азии: история и современность (на примере Тувы, Тофаларии, Калмыкии и Монголии».

Для цитирования: Сувандии Н. Д. Официальные и «вторые» имена этнических тувинцев Монголии. Oriental Studies. 2019;(4):661-668. DOI: 10.22162/2619-0990-2019-44-4-661-668. 
UDC 81’373.23

\title{
Ethnic Tuvans of Mongolia: Official and 'Second' Names
}

\author{
Nadezhda D. Suvandii ${ }^{1}$ \\ ${ }^{1}$ Tuvan State University (9/B, Mongush Sat St., Kyzyl 667000, Russian Federation) \\ Cand. Sc. (Philology), Associate Professor \\ ORCID: 0000-0002-3817-2436. E-mail: suvandiin@mail.ru
}

\begin{abstract}
Introduction. The article analyzes personal names and nicknames of Mongolia's ethnic Tuvans which is an understudied - though topical - issue of contemporary Tuvan onomastics. The 'second' names contain data about old and modern culture of foreign Tuvans, and particularly that of Mongolia-based ones. Goals. The article primarily seeks to identify official, 'home', and 'paired' names (i.e. nicknames) of Tuvans residing in Western Mongolia. To date, this aspect of Tuvan linguistics has been no object of any special scientific research. So, the work can fill the gap, and facilitate further development of Tuvan onomastics in general. Materials. The paper analyzes personal names and 'second' names collected by the author during field research in Bayan-Ölgii and Khovd Provinces of Mongolia inhabited by ethnic Tuvans. Results. The analysis of personal names and nicknames concludes that the official documents of the latter mention personal names of TibetanMongolian origin, while in everyday life they actually use 'second' names that deal with the history, customs and traditions of their ancestors. In the past, both essentially Tuvan and Tibetan-Mongolian names served as 'household' and 'paired' ones, while the current period witnesses the additional use of hypocoristic forms which is a novelty to name-giving practices of Mongolia's Tuvans.

Keywords: Tuvan language, onomastics, anthroponymy, personal names, nicknames, 'second' names, 'home' names, 'paired' names

Acknowledgment: The reported study was funded by RFBR, project number 19-012-00073 'Transformational Processes in Onomastics of the Peoples of Central Asia: History and Modernity (using the example of Tuva, Tofalaria, Kalmykia and Mongolia)'.

For citation: Suvandii N. D. Ethnic Tuvans of Mongolia: Official and 'Second' Names. Oriental Studies. 2019; (4): 661-668. DOI: 10.22162/2619-0990-2019-44-4-661-668.
\end{abstract}

\section{है}

\section{Введение}

Разнообразный состав личных имен каждого народа содержит богатый лингво-этнографический материал, связанный с историей и современным его состоянием.

Антропонимия тувинцев Монголии в своем составе хранит и содержит информацию о прошлом народа, его повседневном быте и образе кочевой жизни, что делает актуальным проведение ее исследования. Важным аспектом научного изучения антропонимии тувинцев является выявление общего и особенного в ономастике тувинцев зарубежья и России.

Основателем исследования тувинской антропонимической системы является Н. Ф. Катанов, который в своем капитальном труде дает перечень некоторых соб- ственных имен [Катанов 1903: 659]. Спустя более полувека после выхода грамматики Н. Ф. Катанова вопросами антропонимии тувинского языка начала заниматься 3. Б. Чадамба - одна из первых исследователей тувинского языка. Она в своей первой работе дает сведения о личных именах тувинского народа [Чадамба 1965: 174-177]. Вскоре после этой работы известный советский и российский этнограф, археолог, востоковед-тюрколог, специалист по проблемам истории, этнографии и археологии Тувы С. И. Вайнштейн в одной из научных статей освещал личные имена и прозвища тувинцев [Вайнштейн 1969: 125-162].

Один из первых тувинских языковедов Д. А. Монгуш в своей научной работе впервые затронул вопрос о сокращенных лич- 
ных именах в разговорной речи населения и в художественной литературе [Монгуш 1973: 146-155].

В начале 90-х гг. ХХ столетия была опубликована следующая работа 3. Б. Чадамба, в которой автором даны сведения о некоторых семантических группах и способах образования тувинских личных имен [Чадамба 1993: 98-105].

Антропонимам монгольского, тибетского и санскритского происхождения в тувинском именнике была посвящена в 2001 г. дипломная работа Р. Д. Лудуп, в которой автор описывал семантические группы, этимологию личных имен, заимствованных из монгольского и через него из тибетского языка и санскрита; к этой работе в качестве приложения был дан краткий словарь монгольско-тибетских личных имен.

В конце 1990-х гг. - начале 2000-х гг. автором данной статьи опубликован ряд научных статей и написана кандидатская диссертация, в которой рассмотрены основные лексико-семантические группы, структурные типы тувинских антропонимов, происхождение иноязычных личных имен и их современное состояние [Сувандии 2004] и т. Д.

Антропонимическая система тувинского языка в целом рассмотрена учеными. Но личные имена этнических тувинцев Монголии до настоящего времени остаются почти неисследованными. Изучение антропонимии тувинцев Западной Монголии представляет большой интерес у тувиноведов в связи с тем, что у них встречаются имена, которые употреблялись и употребляются не только у монгольских, но и у российских тувинцев - в данном случае в основном как официальные.

Цель настоящей статьи - изучение личных имен и прозвищ у этнических тувинцев Западной Монголии, которые компактно проживают в сомоне Буянт и г. Кобдо (Ховд) Кобдоского аймака, в сомоне Цэнгэл, на таежных чабанских стоянках в местечках Харааты, Остуг, Беш-Богдо Баян-Ульгийского аймака.

Материалом для нашего исследования послужили данные полевых экспедиций, проведенных в вышеназванных аймаках Монголии в 1999, 2001, 2019 гг. Первые две комплексные научные экспедиции были организованы Тувинским государственным университетом с целью сбора языкового, устно-поэтического, этнографического, исторического материалов. В составе экспедиций были не только ученые университета, но и аспиранты, студенты, в задачи которых входили сбор материалов и написание на их основе соответственно курсовых и дипломных работ, диссертаций. Материалы в основном собирались методами анкетирования и устного опроса местного населения Кобдоского аймака Монголии. Третья экспедиция состоялась в 2019 г. при поддержке РФФИ, в ее составе работали два языковеда, этнограф, а также магистрант — выходец сомона Цэнгэл Баян-Ульгийского аймака. Целью этой экспедиции являлся сбор ономастического материала у тувинцев Кобдоского и Баян-Ульгийского аймаков по теме проекта; по ее результатам продолжается работа по написанию научных статей.

Особенности наречения официальным именем и прозвищным наименованием у этнических тувинцев Монголии

У тувинцев Монголии, как отмечалось выше, наряду с официальными именами имеются прозвищные наименования, так называемые өг атmapы 'домашние имена' у кобдоских, кош аттар 'парные имена' у цэнгэльских тувинцев. Следует отметить, что у каждого тувинского представителя аймаков Монголии, кроме официального, обязательно присутствуют такие вторые имена, тогда как у российских тувинцев это необязательная традиция.

Прежде чем рассмотреть официальные и прозвищные наименования, следует кратко остановиться на имянаречении ребенка. Материалы по имянаречению собраны автором путем опроса информантов в двух аймаках Монголии и представителей двух районов Тувы, которые проживают в доме-интернате для пожилых людей в г. Кызыле.

В двух исследуемых аймаках Монголии имеются сходные и разные виды имянаречения.

По данным информантов Кобдоского аймака [ПМА: инф.1] Монголии, в прежние времена по истечении трех дней после рождения ребенка в аале (поселении, включающем три и более юрт родственников) собирали родственников и устраивали небольшой пир, где угощали их заранее приготовленной «белой» пищей и мясом, в частности курдюком барана. Самый старший и уважа- 
емый человек давал имя ребенку, которое родители беспрекословно принимали, так как слово старшего для них было законом. Нарекали в те времена как монгольскими, так и собственно тувинскими именами.

У жителей сомона Цэнгэл Баян-Ульгийского аймака Монголии зафиксирован сходный обычай имянаречения, но с небольшим отличием: через три дня после рождения ребенка родители устраивают праздник, куда приглашаются родные и близкие с семьями, особенно дяди по материнской линии, старшие по возрасту жители соседних аалов, а также хиндик ээджи хиндик авазы (букв. 'пуповинная мать', т. е. 'женщина, обрезавшая пуповину при родах'). Всех приглашенных гостей угощают мясом и «белой» пищей, почетному гостю, который дал подходящее имя ребенку, преподносят небольшой подарок: ткань размером, достаточным для шитья национальной длиннополой (распашного типа) одежды с длинными рукавами, плиточный чай или шкура зарезанного на пир барана [ПМА: инф. 2, 3].

По данным некоторых информантов [ПМА: инф. 4], в сомоне Цэнгэл существует также обычай под названием Кавайынга каар 'Положить в колыбель'. Через 3-5 дней после рождения ребенка устраивают праздник, куда приглашают близких родственников, угощают их заранее приготовленной мясной и молочной пищей. Каждый приглашенный пишет на небольшом листке бумаги имя и помещает его в специально приготовленную тарелку с рисовой крупой, а также кладет свой подарок (или деньги) в колыбель малыша, говоря благопожелание ребенку. Затем самый старший в аaле человек или отец смешивает все листки бумаги в рисовой крупе, достает один из них и шепчет записанное на нем имя на ухо ребенку. Следует отметить, что у этнических тувинцев Монголии до настоящего времени существуют прежние обычаи имянаречения, но с некоторыми изменениями. Данный обычай имянаречения близок к обычаю тувинцев России, где родители новорожденных также приглашают к себе на праздник близких родственников, угощают мясом и «белой» пищей. Но, в отличие от обычая имянаречения у монгольских тувинцев, они просят всех гостей написать имена на небольших листках бумаги, кладут их в заранее приготовленную шапку, смешива- ют и оттуда выбирают один листок, начертанное на нём имя станет именем ребенка [ПМА: инф. 5,6$]$. У российских тувинцев из описанных выше двух обычаев имянаречения в настоящее время редко встречается только второй вариант обычая, и только в некоторых селах, в частности в Эрзинском, Барун-Хемчикском районах, а большинство родителей-тувинцев ходят к ламам в монастыри и обращаются к ним с просьбами об имянаречении ребенка исходя из даты рождения младенца.

\section{Особенности официальных и «вто- рых» имен тувинцев Монголии}

«Вторые» имена этнических тувинцев Монголии - өг атmары 'домашние имена' или кош аттар 'парные имена', в большей части характеризуют новорожденного. Их можно подразделить на ряд лексико-семантических групп, часть которых была ранее выявлена автором данной статьи [Сувандии 2011: 207].

1. Имена, характеризующие внешность и особенности строения тела ребенка: Коңcaй (м.) - от прилагательного ховд., цэнг. коңсугур, лит. коңзагар 'нос с горбинкой' [ТРС 1968: 252] — дано ребенку с большим носом; Баккыр (м.) - от ховд., цэнг. баккыр лит. баштыл 'с головой' [ТРС 1968: 96], Калчан (м.) - от прил. калчан 'лысый, плешивый' (у ребенка на голове не было ни одной волосинки) [ТРС 1968: 222], Делдиң (м.) монг. дэлдэн, тув. делбиң 'оттопыренный’ (у малыша оттопыренные уши) [ТРС 1968: 145], Дөрбелчин (м.) - от прил. дөрбелчин 'квадратный' (упитанный, сильный, здоровый малыш) [ТРС 1968: 178] и др. В тувинской антропонимии подобные личные имена, кроме Баккыр, часто употребляются в качестве официальных, за исключением некоторых имен, используемых в качестве прозвищ: Дөрбелчин, Делдиң Делбиң.

2. «Вторые имена», связанные с названиями животных и птиц: Хурган (м., ж.) от сущ. ховд., цэнг. хурга(н) 'ягненок' [MРС 1947: 566], лит. хураган 'ягненок', Хенче (м., ж.), Хенче-оол (м.) - от хенче 'рожденный осенью' (о молодняке мелкого скота) [ТРС 1968: 474] — домашнее имя самого младшего ребенка в семье, Анай Аный (м., ж.) от анай 'козленок' [ТРС 1968: 59], Авырган (м.) от нарицательного имени авырга 'белка-летяга' [ТРС 1968: 33], Ботхан (м.) - от монг. богто 'верблюжонок' [РМС 1960: 
60], тув. бодаган 'верблюжонок' [ТРС 1968: 107], Морсук (м.) от ховд., цэнг. морсук лит. морзук 'барсук' [ТРС 1968: 299], Кушкаш (ж.) - от сущ. кушкаш 'птица' [ТРС 1968: 267] и др.

Число имен, включаемых в данную группу, небольшое, но они употребляются часто, особенно такие кош аттар 'парные имена', как Анай, Хенче. В антропонимии тувинцев зарубежья личные имена данной лексико-семантической группы у лиц старшего возраста являются одними из часто употребительных.

3. «Вторые» имена, связанные с цветовыми характеристиками малышей: Көк (м., ж.), Көк-оол (м.), Көгерген (ж.) - от прил. көк 'синий' [ТРС 1968: 257] (при рождении малыш был синюшным), Хараa (м., ж.), Xaралдай (м.) - от монг. хар 'черный' [МРС 1947: 512], тув. кара 'черный' [ТРС 1968 : 226] (родился смуглый ребенок), Кызыл (м.) — от прил. кызыл 'красный' [ТРС 1968: 274] (при рождении новорожденный был красным), Сарыblкы (м.) - от монг. шар 'желтый, рыжий' [MPC 1947: 645], тув. сaрыг 'желтый' [ТРС 1968: 369] и др. Личные имена данной группы у этнических тувинцев Монголии являются только «вторыми», а в современном именнике тувинцев России они часто употребительны.

4. Редко, но отмечаются и «вторые» имена, связанные с этнонимами, как и в других тюркских языках: Адай (м.) - от этнонима адай иргит, Халха (м.) - от хал$x a$, тув. калга 'название монгольского народа, составляющего основное население Монголии', Казак-оол (м.) - имя, данное в честь соседей-казахов у тувинцев сомона Цэнгэл. Подобные антропонимы в современном тувинском языке также встречаются в качестве официального личного имени: Орус-оол (м.) - от этнонима орус 'русский' [ТРС 1968: 328], Монгул, Монгул-оол (м.) от этнонима монгул монгол, Хакас (ж.), Хакас-оол (м.) — от этнонима хакас и т. п. Предки тувинцев издавна творчески относились к имянаречению своих детей, при этом имена данной группы свидетельствуют об уважительном отношении их к новым соседям; подобные имена фиксируются и у тувинцев России.

5. К следующей группе относятся «вторые» имена, связанные с пожеланием стойкого характера и темперамента ребенку:
Мерген (м.) - от прил. мерген 'меткий, мудрый' [ТРС 1968: 293], Сергекпен (м.) - от прил. сергек 'бодрый, живой’ [ТРС 1968: 374], Омаакай (м.) - от прил. омак 'веселый, бодрый’ [ТРС 1968: 319]. У тувинцев зарубежья это «вторые» имена, а у тувинцев России - официальные.

6. У тувинцев сомона Цэнгэл зафиксированы также «парные» имена, указывающие на те или иные недостатки, качества носителя имени: Аазатпай (ж.) - от прил. аазатпай 'разиня, ротозейка' (речь идет о флегматичном, медлительном ребенке) [ТРС 1968: 26], Мугулай (м.) — от прил. мугулай 'глупый’ [ТРС 1968: 302], Дунуху (м.) - от цэнг. дун,ху синоним тув. чоон 'толстый' [ТРС 1968: 540] (в данном случае, по словам информатора, означает 'с толстой шеей'), Маңзыгыр (м.) - от прил. маңзыгыр син. аaр 'массивный, тяжелый' [РТС 1980: 248] (в данном случае имеется в виду голова), Ко(ъ)шпай (м.) - от прил. ко(ъ) u 'парный' [ТРС 1968: 254] (у ребенка на ушке отросток, похожий на сережки) и др.

7. Этнические тувинцы Монголии в качестве «вторых» имен в последнее время дают детям имена, связанные с природными явлениями, как в современном именнике тувинцев России: Айдың, Айдың-оол (м.) от прил. айдың 'лунный' [ТРС 1968: 47] и оол 'мальчик' [ТРС 1968: 322], Шолбан, Ак-Шолбан (м.) — от сущ. шолбан 'яркая звезда, Венера' [ТРС 1968: 577] и прил. ак 'белый' [ТРС 1968: 49], Ай-XYY (м.) — от сущ. ай 'луна' [ТРС 1968: 46] и монг. ХХY [РМС 1960: 296], тув. оол 'мальчик' [РТС 1980: 322], Сылдысс (м., ж.), Чыллдысс (м.) от сущ. сылдыс 'звезда' [ТРС 1968: 397].

Число личных имен в данной группе небольшое, но встречаются они часто, причем у некоторых молодых людей в возрасте не старше 30 лет они зафиксированы как официальное имя. В имениннике тувинцев России имена указанной группы являются часто употребительными.

8. У некоторых цэнгэльских тувинцев замечены единичные «парные» личные имена: Мөңъгүн (м.) - от сущ. мөңзгүн 'серебро' [ТРС 1968: 301], Алдын (м., ж.) — от сущ. алдын 'золото' [ТРС 1968: 54].

9. Отмечаются «вторые» личные имена-посвящения: Алдар (м.) - от сущ. алдар 'слава' [ТРС 1968: 54] — имя, данное в честь прадеда, который участвовал в боях 
на Халхин-голе ${ }^{1}$; Конгар-оол (м.) - имя-посвящение, данное мальчику, родившемуся в 90-х гг. ХХ столетия, когда в сомон Цэнгэл приезжал заслуженный артист Российской Федерации, Народный хоомейжи ${ }^{2}$ Конгар-оол Ондар; Чылльичы (м.) - от сущ. чыллгычы ‘табунщик' [ТРС 1968: 555], в честь известного тувинского драматурга, который в свое время был министром культуры Тувинской АССР, послом РФ в Казахстане.

10. Есть у этнических тувинцев и имена-пожелания: Орулгу (м., ж.) от монг. оролго, тув. орулга 'доход, прибыль' [ТРС 1968: 327], «парное» имя, данное с пожеланием жизни в достатке; Хоочун (м.) - от сущ. хоочун 'старый, бывалый', данное с пожеланием долгой жизни [ТРС 1968: 484]; $O x$ тун (ж.) - вероятно, от монг. отгон 'самый младший, последний ребенок', хотя в обоих случаях носители этого имени - цэнгэльские тувинцы дали следующее объяснение: имя происходит от сущ. монг. огтхон 'решительно возражаю' [МРС 1947: 293] и дано с пожеланием, чтобы девочку не забрали духи, так как ранее рождавшиеся в этой семье девочки умирали от различных болезней.

11. В отдельную группу следует выделить «домашние» или «парные имена» с уменьшительно-ласкательным значением, которые, по словам информантов [ПМА: инф. 3], стали давать с начала 2000-х гг: Баака (ж.) 'маленькая' - от монг. бага 'малый, небольшой', по словам информантов [ПМА: инф. 4], в значении 'маленький ребенок' [МРС 1947: 53], Тойлоо (ж.) 'зеркальце' - от толь (толии) 'зеркало' [MPC 1947: 406; РMC 1960: 213] — в значении 'зеркало семьи', так как ребенок с этим именем - единственная дочь в семье [ПМА: инф. 4], Анхаа (ж.) 'первенец' - от монг. анх первый [МРС 1947: 39] — 'первый, старший ребенок семьи', Баавгай (м.) 'медвежонок' - от монг. баавгай 'медведь' [MPC 1947: 52] — так при рождении назвали пухленького, смуглого мальчика [ПМА: инф. 2], Муужулдай (м.) 'отброшенка' — от монг. мужуулах ‘быть отброшенным в сто-

${ }^{1}$ Необъявленный локальный вооружённый конфликт, продолжавшийся с весны по осень 1939 года у реки Халхин-гол на территории Монголии.

${ }^{2}$ Хоомейжи - исполнитель горлового пения. рону' [МРС 1947: 248] — ребенок в детстве сильно болел, поэтому дали такое «парное» имя, чтобы злые духи его не заметили, $T_{Y м е-}$ нек (м.) 'тьмушенька' — от монг. түмэн 'тьма, бесчисленное множество' [МРС 1947: 431] — такое имя могли дать, когда в семье родился ребенок после долгого ожидания, Хенчитей (ж.) 'младшенький' - от тув. хенче 'рожденный осенью' (о молодняке мелкого скота) - «парное» имя самого младшего ребенка семьи в уменьшительной форме и т. д.

В данной группе почти все имена - как монгольского происхождения, так и исконно тувинские - использованы в уменьшительно-ласкательной форме. Исходя из этого следует отметить, что этнические тувинцы Западной Монголии в большинстве имеют два имени: как официальное, так и «второе», причем многие из них в современном именнике тувинцев России употребляются как личные имена: Алдын, Тумен, Шолбан, Сылдысмаа и т. д.

Заключение. Тувинская антропонимия - это «хранительница» древней истории, обычаев и традиций народа. Как особая группа антропонимии в тувинской ономастике нами выявлена группа «вторых» имен тувинцев Кобдоского и Баян-Ульгийского аймаков Западной Монголии, которые указывают на особенности их имянаречения. В двух исследуемых аймаках такие имена отличаются общим наименованием - $ө 2$ aтmары «домашние» имена в Кобдоском аймаке, кош аттары «парные» - в Баян-Ульгийском. Из рассмотренного материала видно, что в целом обычаи имянаречения близки, за исключением некоторых отличий, зафиксированных у тувинцев сомона Цэнгэл Баян-Ульгийского аймака. Лексико-семантические группы бытующих «вторых» имен в целом общие, но у цэнгельских тувинцев встречаются имена, связанные с этнонимами, типа Казак-оол.

У каждого этнического тувинца Монголии должно иметься «второе» («домашнее» или «парное») имя, которым его нарекают дома - это и есть основное отличие его от прозвища. У тувинцев России, в отличие от этнических тувинцев Монголии, вообще нет «вторых» имен, а есть только прозвища, которые употреблялись в их повседневной жизни еще с древних времен и бытуют также в современное время (хотя 
прозвища имеются не у всех представителей российских тувинцев). Тем не менее они также близки ко «вторым» именам этнических тувинцев Монголии, так как во времена паспортизации в 40-х гг. ХХ в. тувинцы России в качестве официальных имен взяли интернациональные личные имена, а свои прежние оставили в качестве прозвищ, в которых отражены самобытная культура этноса в определенные периоды в их жизни. По словам ветерана Тувинского государственного университета, проработавшей всю жизнь доцентом кафедры тувинской филологии и общего языкознания Елизаветы Боракаевны Салзынмы, будучи школьницей во время паспортизации, она взяла себе имя Лизы Чайкиной, а свое имя оставила в качестве фамилии. В отличие от «вторых» имен этнических тувинцев Монголии, прозвища тувинцев России даются уже взрослым людям, притом не

\section{Сокращения}

ж. - женское

м. - мужское

монг. - монгольское

прил. - имя прилагательное

сущ. - имя существительное

тув. - тувинское

ховд. - ховдинский диалект

цэнг. — цэнгэльский диалект

\section{Полевой материал автора}

ПМА: инф. 1 - информант Адай Иргит Карбычап оглу Буурлак, 1909 г. р., запись в сомоне Буянт Ховдского аймака Монголии, 1999 г.;

ПМА: инф. 2 - информант Хойук Элээ кызы Дэлгир, 1936 г. р., сомон Цэнгэл, 2019 г.;

ПМА: инф. 3 - информант Донгак-хойук Долгар-Сурун оглу Хойтувек, 1934 г. р., сомон Цэнгэл, 2019 г.;

ПМА: инф. 4 - информант Шунгуур Иргит Чамбаа кызы Оюун, 1960 г. р., сомон Цэнгэл, 2019;

ПМА: инф. 5 - информант Монгуш Сынаа Намчылович, 1932 г.р.; с. Аянгаты, Барун-Хемчикского района Республики Тыва, $2001 \Gamma$;

ПМА: инф. 6 - информант Кунчун Вера Манчыновна, 1935 г. р., с. Эрзин, Республика Тыва, 1999 г. только исконно тувинские, но и немало заимствованных из русского языка: Бугажык (м.) - прозвище человека, занимавшего небольшие руководящие должности, Бегемот (м.) - человек крупного телосложения, Повар (ж.) - женщина, всю жизнь проработавшая поваром, Барби (ж.) - красивая, как кукла, женщина и т. п.

Таким образом, следует сказать, что предки тувинцев России и Монголии имели общую историю и культуру, так как этнические тувинцы Монголии имели «вторые» имена, а тувинцы России - соответственно прозвища. В настоящее время у этнических тувинцев «парные» и «домашние» имена так и функционируют, а у тувинцев Республики Тыва употребляются не только собственно тувинские, но и заимствованные из русского языка прозвища, что свидетельствует об их связи в современном обществе.

Author's Field Data

Informant 1: Aday Irgit Karbychap oglu Buurlak, b. 1909. Rec. in Buyant District (Khovd Province, Mongolia) in 1999;

Informant 2: Khöiük Elee kyzy Delgir, b. 1936. Rec. in Tsengel District (Bayan-Ölgii Province, Mongolia) in 2019;

Informant 3: Dongak-khöiük Dolgar-Surun oglu Khöitüvek, b. 1934. Rec. in Tsengel District (Bayan-Ölgii Province, Mongolia) in 2019;

Informant 4: Shunguur Irgit Chambaa kyzy Oyuun, b. 1960. Rec. in Tsengel District (Bayan-Ölgii Province, Mongolia) in 2019;

Informant 5: Mongush Synaa Namchylovich, b. 1932. Rec. in Ayangaty (Barun-Khemchiksky District, Tyva Republic) in 2001;

Informant 6: Kunchun Vera Manchynovna, b. 1935. Rec. in Erzin (Erzinsky District, Tyva Republic) in 1999.

\section{Литература}

Вайнштейн 1969 - Вайнштейн С. И. Личные имена, термины родства и прозвища у тувинцев // Ономастика. М.: Наука, 1969. C. $125-132$.

Катанов 1903 - Катанов Н. Ф. Опыт исследования урянхайского языка с главнейшими родственными отношениями его к другим языкам тюркского корня. Казань: типо-лит. Имп. Казан. ун-та, 1903. 659 с. 
МРС 1947 - Монгол-орос товч толь бичиг (= Краткий монгольско-русский словарь) / под ред. А. Р. Ринчинэ и Г. Д. Санжеева. М.: ОГИЗ-ГИС, 1947. 424 с.

Монгуш 1973 - Монгуи Д. А. Сокращенная форма личных имен в тувинском языке // Ученые записки ТНИИЯЛИ. Кызыл: ТНИИЯЛИ, 1973. С. 146-155.

РМС 1960 - Русско-монгольский словарь. М.: Гос. изд-во иностр. и национ. словарей, 1960. $780 \mathrm{c}$.

РТС 1980 - Русско-тувинский словарь. М.: Русский язык, 1980. 560 с.

Сувандии 2004 - Сувандии Н. Д. Тувинская антропонимия: дисс. ... канд. филол. наук. Кызыл, 2004. 191 с.

Сувандии 2011 - Сувандии Н. Д. Тувинская антропонимия. Кызыл: ТувГУ, 2011. 207 с.

ТРС 1968 - Тувинско-русский словарь. М.: Советская энциклопедия, 1968. 646 с.

Чадамба 1965 - Чадамба 3. Б. Тувинские имена // Справочник личных имен народов РСФСР. М.: Русский язык, 1965. С. 174-177.

Чадамба 1993 - Чадамба 3. Б. Способы образования тувинских личных имен // Вопросы тувинского языкознания. Кызыл: Новости Тувы, 1993. С. 98-105.

\section{References}

[A Concise Mongolian-Russian Dictionary]. A. Rinchine, G. Sanzheev (eds.). Moscow: Associated State Publ. (OGIZ), 1947. 713 p. (In Russ. and Mong.)
[Russian-Mongolian Dictionary]. Moscow: Foreign and National Dict. Publ., 1960. 780 p. (In Russ. and Mong.)

[Russian-Tuvan Dictionary]. Moscow: Russkiy Yazyk, 1980. 560 p. (In Russ.)

[Tuvan-Russian dictionary]. Moscow: Sov. Entsiklopediya, 1968. 646 p. (In Russ.)

Chadamba Z. B. Tuvan personal names: wordforming patterns. In: [Questions of Tuvan Linguistics]. Kyzyl: Novosti Tuvy, 1993. Pp. 98-105. (In Russ.)

Chadamba Z. B. Tuvan names. In: [Personal Names of Soviet Peoples: a Reference Book]. Moscow: Russkiy Yazyk, 1965. Pp. 174-177. (In Russ.)

Katanov N. F. [A Research Essay on the Uriankhai Language with Indication of Its Key Essential Ties to Other Turkic Languages]. Kazan: Imper. Kazan Univ., 1903. 659 p. (In Russ.)

Mongush D. A. Hypocoristic forms of Tuvan personal names. In: [Scholarly Notes of the Tuvan Research Institute of Language, Literature and History]. Kyzyl: Tuvan Res. Inst. of Lang., Liter. and Hist., 1973. Pp. 146-155. (In Russ.)

Suvandii N. D. [Tuvan Anthroponymy]. A Cand. Sc. thesis (philology). Kyzyl, 2004. 191 p. (In Russ.)

Suvandii N. D. [Tuvan Anthroponymy]. Kyzyl: Tuvan State Univ., 2011. 207 p. (In Russ.)

Vainshtein S. I. Personal names, kinship terms, and nicknames of the Tuvans. In: [Onomastics]. Moscow: Nauka, 1969. Pp. 125-132. (In Russ.) 